\title{
MINIPLIER AND ACCUMULATING USELESSNESS AS NEW REALITY OF TOURISM ECONOMY UNDER PANDEMIC
}

\author{
Denis USHAKOV*

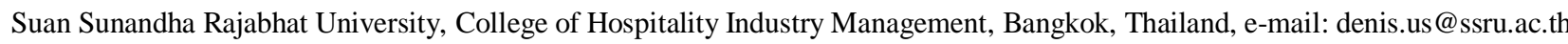

Ekaterina ANDREEVA

Rostov State Transport University, Department of Tourism Industry Management, Rostov-on-Don, Russia, e-mail: eva-rgups@mail.ru

Citation: Ushakov, D., \& Andreeva, E. (2021). MINIPLIER AND ACCUMULATING USELESSNESS AS NEW REALITY OF
TOURISM ECONOMY UNDER PANDEMIC. GeoJournal of Tourism and Geosites, 39(4spl), $1363-1370$.
https://doi.org/10.30892/gtg.394spl06-779

\begin{abstract}
Stemming from the statistical data on tourism trends during 2018-2020 and author's own methodology of calculating the efficient tourist multiplier, to determine regularities and factors behind the reaction of the leading world economies to the critical fall in tourist services production under the coronavirus pandemic conditions. The research study is based on the statistical analysis of tourists' spending impacts on the dynamics of nominal GDP in 48 countries of the world and also on the author's own approach to determining the efficient tourist multiplier (miniplier in this case) as well as on the hypothesis about the accumulating uselessness of tourist services production. We have detected regularities in the dynamics of tourist multiplier as well as in restructuring of tourist services production in the leading economies of the world under the conditions when the tourist market environment was critically worsening. In the research the trends of tourist multiplier for 2018-2020 were determined and also recommendations on modernization of the state regulation system as well as on corporate strategizing were offered, taking into account the author's methodology of measuring the tourism efficiency multiplier (miniplier) and accumulating uselessness of tourist services production under crisis.
\end{abstract}

Key words: medical tourism, healthcare, medical services, insurance, Thailand, Russia

\section{INTRODUCTION}

Socioeconomic efficiency of tourism is obvious since it is directly connected with:

-the growth of a national tourist services production (creation of new objects within the tourist industry, modernization and efficiency increase for the already existing objects of tourist infrastructure and suprastructure; more tax payments leading to better social infrastructure in the country; growing number of people employed in the tourism sector; extra economic benefits from the growing popularity of tourist resources and tourist types of activity);

-the growth of investment attractiveness of the local tourism industry (thus leading to its higher profitability and better quality of the provided tourist services as well as to popularization of a tourist region in the home country of investors);

-attraction of personal savings from foreign tourists. Excellent quality of tourist infrastructure, vast opportunities for organization of leisure and entertainment activities, well-functioning market mechanisms in the region, low criminality rate, overall safety and security of the visitors' health, life and belongings - these are the primary factors behind the tourists' decision to spend more while they are staying in a particular destination.

Thus, inbound tourism is capable of providing the local markets with additional foreign currency resources, thus improving the payment balance of a region and the recipient country overall. Many authors (Archer and Owen, 1971; Armstrong and Taylor, 1985; Coccossis and Nijkamp, 1995; Milne, 1987; Pepping and Bruijn, 1991; Pleeter, 1980; Merrifield, 2006) understood the impact of inbound tourism on the economy of a recipient region in its relation with the growth of savings attracted from the visiting foreigners as an indirect effect, the strength of which is determined with the help of the tourist multiplier - the ratio showing how regional profit depends on tourists' spending.

Tourists' spendings are distributed across various subjects of the local market level by level - from a producer of a final tourist product to producers of various components within this tourist product (for example, from tour operators to hotels, transportation companies, restaurants and so on), excluding though the share which by default belongs to a tour operator. The size of this share would depend on the volume of savings planned by this tour operator (the larger is this volume, the smaller would be the share passed to the second level - to suppliers of various tourist services). Tour operator's share would also depend on the volume of taxes to be paid as well as on the volume of credit obligations.

In their turn, suppliers of tourist services getting their shares of profit from a tour operator are then able to settle their accounts and bills (for example, to pay for utilities, to pay salaries to their employees, to pay to their suppliers, etc.). Therefore, the initial amount paid by a tourist is becoming gradually smaller (and the size of each iteration would depend on the saving, tax and credit necessities of each subject working at the tourist market). Moving from a tour operator to suppliers of tourist services and then other market participants, tourist spending creates profit at every stage of this

\footnotetext{
${ }^{*}$ Corresponding author
} 
transition. Despite all the tragic consequences of the coronavirus pandemic, the year 2020 has provided a unique opportunity to study not only stimulating, multiplicative impact of tourism under volatile, yet stable global growth, but also under crisis conditions — when the growth became nearly $-50 \%$. This problem of a destimulating impact on a national economy due to rapid shortage of all international and internal tourist flows became the core of our research study, thus predetermining its objectives and tasks. Research objectives: to test the reaction of the economic systems in the contemporary states on the critical fall in tourist services production, using the available statistical data and the author's own methodology of calculating the efficient tourist multiplier; to determine its regularities and consequences for modernization of the whole system of state regulation and corporate strategizing within the industry. Research tasks:

-to suggest and explain the author's own methodology of calculating the efficient tourist multiplier taking into account its multifaceted nature;

-to analyze the statistical data as of 2020 which outlines the fall of tourist services production and drop in the nominal GDP in 48 countries of the world so that to determine the contents of the restructuring process at their national tourist markets along with the behavior of the tourist multiplier;

-to ground the time lag and the long-term impacts of the tourist services production dynamics on the growth/fall of the economic systems in the selected countries of the world;

-to evaluate the scale of the destimulating impact of the tourist sector condition on the GDP values in the selected countries.

Prior to the research state we have put forward the following hypotheses:

-The destimulating effect of the tourist spending shortage around the world during 2020 was more serious in those countries that back in 2019 had had the largest shares of income from tourism in their GDPs;

-The potential of internal tourism in the majority of countries (even those that are territorially and demographically large and have an already differentiated and competitive internal tourist product) would not be sufficiently large to overcome the disastrous consequences from the drastic drop in international travels.

-Efficient tourist multiplier (which reveals the degree of foreign and internal tourists' spending on the growth of nominal GDP) will be higher in the countries with more developed, capacious and less import-dependent tourism industries.

-The destimulating impact of the tourism industry collapse on the growth of GDP, same as the effect from the tourist growth, tends to reveal itself in a long (more than a year) term due to sophisticated nature of tourism integration into the structure of a national economy and multilevel structure of tourism infrastructure.

-Tourism industry demonstrates the signs of diminishing uselessness which are manifested through reduced destimulating impacts from tourism fall on GDP dynamics.

\section{LITERATURE REVIEW}

In a simplified form, the multiplier model may be presented as what is known in economic science as a simple Keynesian multiplier (Rusu, 2011: 73): where B stands for the marginal propensity to consume, defined as the ratio of changing spending to changing income. The economic sense of this multiplier is as follows: it shows how the equilibrium level of income is growing (within the closed economy) due to higher spending per unit. Due to recirculation of incomes their total impact on the economy of a country would be significantly stronger than the impact from direct current spending of tourists in the same country, and this is exactly what tourist multiplier is expected to show (Rusu, 2011).

However, we need to keep in mind the partial losses since the obtained income does not stay in a country/region in its full volume. There can be at least three major types of income losses on the level of a country/region: spending on imports (purchasing imported products and services); personal savings; taxes. Under current conditions of the world economy globalization and international integration processes within the tourism sector, the following factors tend to reduce the multiplicative effect from the inbound tourism: the volume of the income repatriated by foreign owners (or investors) of the tourist sector enterprises (in some countries this type of income could be as high as $40 \%$ of all tourists' spending (Butler, 2012); spending on servicing international credits and debt liabilities of the enterprises belonging to tourism infrastructure and suprastructure; spending on the salaries of personnel working on distance, outside the country (for example, top managers, consultants, marketers and so on); spending on the use of foreign brand names (franchising in the hospitality sector usually takes up to $15 \%$ of income from the recipient destination (Pilon, 2020); spending on international outsourcing (in some cases this category can be attributed to import operations).

Thus, the total of these categories of spending is taken out of the recirculation because region's economy does not get direct value from them, even though the local government gets some tax payments. A share of taxes might eventually return to the region, and this makes the impact of tourism on the development of a regional economy even stronger. For every country the ratio of income from tourism (or its multiplier) would depend on the share of losses. Real-life practice shows that the ratio of tourism income is usually in the range of 100-400\% of all direct spending of tourists, that is, of all direct income (Kim and Kim, 2015; Idahosa, 2019; Bycroft et al., 2007; McDonald, 2009; Clulow and Walters, 2013; Ardahaey, 2011; Brohman, 1996).

The following is needed to increased the multiplier effect from inbound tourism (Verdonkschot, 1994):

-better development of tourism infrastructure;

-stable maintenance of the tourist resource base;

-development market environment and economy of the recipient region overall;

-availability of import-substituting commodities (especially living essentials, foodstuffs, tourism-related goods, etc.);

-local policies being oriented on stimulation of tourist spending during the tour and on discouraging personal savings by local population and enterprises of the local tourism industry. 


\section{Research methodology}

Assessment of separate components within the tourism multiplier should be based on a thorough methodological basis and access to specialized software. At this, for each component of the tourism multiplier we need to take into account its contribution into the related economic sector and social policy of the state. For example, considering the production multiplier (the ratio of indirect impact of tourism on the production sector overall and production volumes in particular), we need to take into account the actual volume of the additional production generated thanks to tourists' spending in a certain region.

Table 1. Classification of countries included In our sample (Source: made by the authors)

\begin{tabular}{|c|c|c|c|}
\hline & \multirow{7}{*}{$\begin{array}{l}\text { By } \\
\text { geographical } \\
\text { regions }\end{array}$} & Western Europe & 15 \\
\hline & & Eastern Europe & 6 \\
\hline & & Pacific Asia & 6 \\
\hline 1 & & South Asia & 2 \\
\hline & & Middle East & 9 \\
\hline & & Africa & 3 \\
\hline & & Americas & 7 \\
\hline \multirow{7}{*}{2} & \multirow{7}{*}{$\begin{array}{l}\text { By the } \\
\text { volume of } \\
\text { national } \\
\text { GDP (by } \\
\text { PPP, as of } \\
2020 \text { ) }\end{array}$} & G20 countries & 15 \\
\hline & & $\begin{array}{l}\text { GDP higher than } 1,000 \text { bln but not } \\
\text { in G20 }\end{array}$ & 5 \\
\hline & & GDP from 500 to 1000 bln USD & 8 \\
\hline & & GDP from 300 to 500 bln USD & 8 \\
\hline & & GDP from 200 to 300 bln USD & 4 \\
\hline & & GDP from 100 to 200 bln USD & 6 \\
\hline & & GDP lower than 100 bln USD & 2 \\
\hline \multirow{5}{*}{3} & \multirow{5}{*}{$\begin{array}{l}\text { By the } \\
\text { level of } \\
\text { material } \\
\text { well-being }\end{array}$} & Super rich countries & 14 \\
\hline & & Rich & 6 \\
\hline & & Average rich & 8 \\
\hline & & Average & 9 \\
\hline & & Average poor & 11 \\
\hline
\end{tabular}

Table 2. Contribution of tourism in GDP of the selected countries, as of 2016-2020 (Source: here and after data from: TC360data)

\begin{tabular}{|c|c|c|c|c|c|c|}
\hline & \multirow{2}{*}{ Countries } & \multicolumn{5}{|c|}{ contribution of tourism in GDP, bln USD } \\
\hline & & 2016 & 2017 & 2018 & 2019 & 2020 \\
\hline 1 & USA & 1438 & 1540 & 1595 & 1666 & 846 \\
\hline 2 & Japan & 352 & 349 & 367 & 390 & 234 \\
\hline 3 & Germany & 299 & 321 & 344 & 353 & 208.8 \\
\hline 4 & Italy & 237 & 253 & 274 & 279 & 132.2 \\
\hline 5 & France & 229 & 242 & 265 & 271 & 123.2 \\
\hline 6 & India & 207 & 233 & 247 & 277 & 121.9 \\
\hline 7 & Mexico & 184 & 198 & 209 & 218 & 91 \\
\hline 8 & UK & 279 & 288 & 310 & 323 & 89.6 \\
\hline 9 & Brazil & 152 & 164 & 152 & 161 & 78 \\
\hline 10 & Spain & 175 & 192 & 211 & 221 & 75.4 \\
\hline 13 & Thailand & 105 & 97 & 109 & 117 & 41,7 \\
\hline 40 & Hungary & 10.1 & 11.6 & 13.2 & 14 & 5.8 \\
\hline 41 & Croatia & 12.4 & 13.6 & 15.2 & 15.9 & 5.7 \\
\hline 42 & Dominican Rep. & 12.4 & 13.2 & 14 & 14.7 & 5.6 \\
\hline 43 & Kazakhstan & 7.9 & 9.1 & 9.3 & 9.2 & 3,9 \\
\hline 44 & Tunisia & 6 & 6.1 & 6.5 & 6.2 & 2.81 \\
\hline 45 & Oman & 6 & 6.5 & 7 & 7.7 & 2.26 \\
\hline 46 & Jordan & 7 & 7.6 & 8.4 & 9.1 & 1.9 \\
\hline 47 & Azerbaijan & 5 & 5.6 & 5.9 & 6.5 & 1.22 \\
\hline 48 & Namibia & 1.3 & 1.4 & 1.45 & 1.5 & 1.02 \\
\hline & $\begin{array}{l}\text { ll } 48 \text { countries } \\
\text { in the sample }\end{array}$ & 4708.19 & 5013.8 & 5282.77 & 5545.5 & 2614.2 \\
\hline
\end{tabular}

However, this principle of building a multiplier stems from the assumption that the multiplier is static in its nature, that is, the conditions are well balanced and there is a linear dependence between the production function and the consumption function. In real life though, this dependence is hardly ever that linear. The disturbing factors here can be: a new investment strategy on production; inflationary processes in the country; rate of a region's economic development overall, etc. Considering these and other additional factors would be possible only when we have a methodology and a software available to account for the contribution of these factors. One of the most important tourism multipliers is the multiplier of income that is demonstrating the impact of tourism on the national budget.

It is valuable primarily because this information is used to forecast the GDP growth. When calculating this multiplier one needs to take into account the principles of "pure economic contribution", that is, the difference between total economic benefits and total economic spending of tourism. In the suggested here research study we have carried out the estimation of tourism multiplier for 48 countries of the world, data as of 2019 and 2020 (that is, under the conditions of negative impact of the pandemic on the industry). Countries in our sample have been distributed both geographically and economically (Table 1). Separately we need to note that we intentionally excluded those countries that managed to demonstrate some economic growth even in 2020 (for example: China, Viet Nam, Korea).

\section{RESULTS}

Contribution of tourism in GDP depends on a variety of factors, thus, its share ranges from country to country (Table 2).

As one can see in Table 2, the contribution of the tourism sector in GDP of various countries across the world during 2016-2019 was growing by about 4-5\% each year, and then, due to the pandemic, it sharply dropped by nearly $50 \%$. The most dramatic reduction in the shares of tourism in GDP was observed in the following countries of our sample: Cyprus (by 85\%), Azerbaijan (81\%), Jordan (79\%), UK (72.4\%) and Morocco (71.4\%). The smallest reductions in the shares of tourism sector were observed in the GDPs of Saudi Arabia, Namibia, Japan, Germany and Pakistan. At the same time, we do not detect any obvious correlation between the dynamics of tourism shares' reduction on the one hand and those shares as of 2019, the size of specific economies (measured as total GDP) and the level of well-being (measured as GDP per capita) on the other. The correlation indicators are $0.32,0.26$ and 0.24 accordingly.

During the four years before the pandemic the world average tourist spending was stably growing in the range of 2.8 $3.2 \%$. Then, during the pandemic, the total spending of both foreign and internal tourists dropped in all 48 countries we are analyzing here. The "leaders" in this reduction (with the fall of over 65\%) were, again, Cyprus, Jordan, Azerbaijan, and then also Greece and Spain — that is, the countries with an obviously dominating share of incoming international tourism. Needless to say, all these countries have been suffering the most during the pandemic. Besides that, all these countries (with the exception of Azerbaijan) are known primarily for beach tourism, and this type of tourism activities is always the first to be abandoned in case of negative externalities manifestation. The least significant drop of total spending by both 
internal and foreign tourists (from $29 \%$ to $47 \%$ ) has been observed in the countries that have very well developed internal tourism subsector prior to the pandemic crisis (USA, Japan, New Zealand, India, Pakistan and Brazil).

In all the countries under analysis (with the exception of Belgium, Poland and Pakistan) reduction in the foreign tourists' spending has led to the nearly automatic growth in the share of internal tourism. The leaders in such structural transformations in tourism were Cyprus (the share of internal tourism grew by $104,5 \%$ (!) — from as little as $9.4 \%$ up to 19.2\%), Thailand (growth by 88\%), Azerbaijan (growth by 70\%), Greece (by 65.6\%), and then also Malaysia, Croatia, Egypt, Jordan, and Spain. Most of these countries (but for Egypt and Jordan) used to have stable outbound tourist flows earlier, under the pandemic conditions these flows were logically redirected on domestic resorts, and this has helped to reformat the structure of sectoral income during 2020. On the other hand, serious reformatting (by at least 5\% and more) of the structure of sector incomes was never observed in the tourism sectors of developed European countries (Germany, France, Belgium, Austria and the UK). The share of internal tourism in the tourist incomes of these countries was rather significant before the pandemic. Growth of internal tourism and the related reformatting of incomes was neither observed in the countries with limited internal demand for tourist services (internal or international), including the Dominican Republic, Pakistan, Brazil, Argentina. Thus, their shares of internal tourism incomes did not change much during 2020.

In relatively developed countries that have high potential of the internal tourism, the growth of demand for the national tourist product due to full closure of all international borders did not actually take place. This was the case for several reasons: geographical peculiarities of these countries (their small territories in particular), the implemented by the state anti-epidemic measures (full lockdown on the level of whole provinces and large cities, even for internal travellers), high prices for the national tourist product. In less developed countries that were initially oriented on foreign guests' inflow in the first place, internal tourism has hardly any chance to compensate for the loss of international travellers. Stemming from the above explanations of what is tourism multiplier, we would like to offer our own methodology of its calculation which is based on the aggregated indicators of the total contribution of tourism into national GDP and the volume of spending carried out by both foreign and local tourists.

Table 3. Tourists' spending (both foreign and internal) in the selected countries, 2016 to 2020

\begin{tabular}{|c|l|c|c|c|c|c|}
\hline & & \multicolumn{5}{|c|}{ tourists' spending, in bln \$ } \\
\cline { 2 - 7 } & Countries & 2016 & 2017 & 2018 & 2019 & 2020 \\
\hline 1 & USA & 980.16 & 1003.5 & 1036.58 & 1207 & 687.8 \\
\hline 2 & Germany & 379.92 & 390.19 & 400.3 & 376.8 & 193 \\
\hline 3 & Japan & 209.22 & 218.11 & 223.13 & 261.7 & 156.7 \\
\hline 4 & Mexico & 134.44 & 138.31 & 142.6 & 368 & 136.4 \\
\hline 5 & India & 203.56 & 213.31 & 229.31 & 170.2 & 109.1 \\
\hline 6 & Italy & 187.96 & 193.89 & 197.44 & 215.1 & 102 \\
\hline 7 & France & 173.2 & 177.78 & 182.94 & 200.8 & 98.7 \\
\hline 8 & UK & 193.28 & 205.21 & 209.23 & 240.6 & 85.1 \\
\hline 9 & Spain & 125.85 & 134.77 & 138.87 & 158.4 & 53.3 \\
\hline 10 & Brazil & 112.67 & 105.89 & 108.82 & 80.5 & 51.7 \\
\hline $\mathbf{1 4}$ & Thailand & $\mathbf{7 0 . 3 9}$ & $\mathbf{7 5 . 1}$ & $\mathbf{8 1 . 0 9}$ & $\mathbf{9 0 . 6}$ & $\mathbf{3 4 . 5}$ \\
\hline 40 & Croatia & 12.08 & 13.03 & 13.44 & 13.3 & 4.8 \\
\hline 41 & Hungary & 9.43 & 9.75 & 10.02 & 11.06 & 4.37 \\
\hline 42 & Dominican R. & 9.43 & 9.83 & 10.25 & 9.7 & 3.73 \\
\hline 43 & Tunisia & 3.66 & 3.93 & 4.1 & 6.03 & 2.56 \\
\hline 44 & Kazakhstan & 5.21 & 5.36 & 5.48 & 6.07 & 2.46 \\
\hline 45 & Oman & 3.61 & 3.83 & 4.05 & 4.7 & 1.9 \\
\hline 46 & Jordan & 5.2 & 5.53 & 6.02 & 6.58 & 1.54 \\
\hline 47 & Azerbaijan & 3.91 & 4.34 & 4.61 & 3.24 & 1.01 \\
\hline 48 & Namibia & 1.54 & 1.48 & 1.58 & 1.41 & 0.78 \\
\hline 48 countries in total & 3519,6 & 3649.8 & 3774.23 & 4239.9 & 2140.8 \\
\hline
\end{tabular}

Table 4. Tourism multipliers of the selected countries, 2016-2020 (Source: authors' own calculations)

\begin{tabular}{|c|l|c|c|c|c|c|}
\hline & & \multicolumn{5}{|c|}{ Tourism multiplier } \\
\cline { 2 - 7 } & Countries & 2016 & 2017 & 2018 & 2019 & 2020 \\
\hline 1 & S. Arabia & 2.12 & 2.09 & 2.07 & 1.50 & 2.07 \\
\hline 2 & Indonesia & 1.65 & 1.73 & 1.70 & 1.77 & 1.93 \\
\hline 3 & Nigeria & 1.60 & 1.55 & 1.46 & 1.85 & 1.88 \\
\hline 4 & Chile & 1.37 & 1.45 & 1.45 & 1.83 & 1.64 \\
\hline 5 & Kazakhstan & 1.52 & 1.70 & 1.70 & 1.52 & 1.59 \\
\hline 6 & Russia & 1.14 & 1.32 & 1.35 & 1.55 & 1.55 \\
\hline 7 & Norway & 1.68 & 1.71 & 1.81 & 2.10 & 1.52 \\
\hline 8 & Brazil & 1.35 & 1.55 & 1.40 & 2.00 & 1.51 \\
\hline 9 & Dominican Rep. & 1.31 & 1.34 & 1.37 & 1.52 & 1.50 \\
\hline 10 & Japan & 1.68 & 1.60 & 1.64 & 1.49 & 1.49 \\
\hline $\mathbf{2 8}$ & Thailand & $\mathbf{1 . 4 9}$ & $\mathbf{1 . 2 9}$ & $\mathbf{1 . 3 4}$ & $\mathbf{1 . 2 9}$ & $\mathbf{1 . 2 1}$ \\
\hline 40 & India & 1.02 & 1.09 & 1.08 & 1.63 & 1.12 \\
\hline 41 & Tunisia & 1.64 & 1.55 & 1.59 & 1.03 & 1.10 \\
\hline 42 & Morocco & 1.60 & 1.68 & 1.75 & 1.67 & 1.09 \\
\hline 43 & Germany & 0.79 & 0.82 & 0.86 & 0.94 & 1.08 \\
\hline 44 & UK & 1.44 & 1.40 & 1.48 & 1.34 & 1.05 \\
\hline 45 & Belgium & 1.14 & 1.18 & 1.25 & 0.96 & 1.02 \\
\hline 46 & Malaysia & 1.20 & 1.21 & 1.28 & 1.13 & 0.97 \\
\hline 47 & Switzerland & 1.25 & 1.25 & 1.25 & 1.28 & 0.87 \\
\hline 48 & Mexico & 1.37 & 1.43 & 1.47 & 0.59 & 0.67 \\
\hline The total of 48 countries & 1.39 & 1.40 & 1.44 & 1.45 & 1.31 \\
\hline
\end{tabular}

Our logical assumption here is that we can draw a parallel between the multiplicative effect from the spending of foreign and local tourists with the volume of indirect contribution of tourism into a country's GDP. Stemming from the already existing definitions of the tourism multiplier, the methodologies used for its calculation are usually based on measuring the economic effect from the means brought into a tourist region by foreign and local tourists, with the deduction of the means extracted from the same region (that is, factors limiting the tourism multiplier). The methodology we would like to offer in this research study is different from the existing ones due to the following:

-we take into account the money assets brought in not only by foreign but also by internal tourists (in other words, we can measure the multiplier for one separate tourist destination, for example). On the one hand, internal tourists are not able to attract new savings and assets into a country. But on the other — they are still contributing to money exchange between the sectors and regions of the same country, thus promoting the growth in economic efficiency of the whole economic system (since, as a rule, money tends to flow from the sectors and region with smaller multiplier effect);

-we do not take into account the factors that are reducing the tourism multiplier (for example, the volume of credit payments, the volume of means moved by tourists out of the country, tax payments, etc.). Consequently, tourism multiplier of a particular destination is being considered taking into account its all peculiarities, including, inter alia, the country of origin of 
the incoming tourists. Therefore, the obtained values of the multiplier may be considered as an efficient multiplier which has aggregated all the factors, including the limiting ones. This corresponds to the pre-set research tasks — to evaluate the economic efficiency of tourism as a whole, as a complex system of interactions between servicing enterprises on both sending and receiving sides. Obviously, tourism multiplier values obtained following this methodology would be significantly different from the results obtained based on the methodologies known earlier. Of course, our values would be much more modest in terms of digits, and in some cases they can be even smaller than 1 (for example, when local tourists spend much abroad, when tax rates are very high, or when there are large payments under foreign credit and/or franchising obligations, etc.);

-finally, our choice of a methodology for calculating tourism multiplier has been also predetermined by the opportunities to obtain official statistical data as of 2020 (on the date when this study was being prepared, July 2021).

Table 4 demonstrates the values of the efficient tourism multiplier for the selected and analyzed countries of the world, 2016 to 2020. As we can see from Table 4, in a range of countries the values of tourism multipliers were less than 1 (Germany, Belgium, Mexico). Consequently, the actual contribution of the tourism sector in GDP is lower than the volume of its direct spending (this might have happened due to, for example, high tax load, strong dependence on foreign labor force, foreign ownership of some assets, the use of foreign credits or foreign brand names and so on). Thus, in such cases, we are not really talking about a multiplier effect from tourism since this effect gets a directly opposite value. In this case we might call the effect "miniplying", and the indicators can be thus renamed as "tourist miniplier".

Also, Table 4 shows that the average efficient tourism multiplier in the countries under analysis was growing during 2016-2019, then it went down, primarily due to the growing share of tourism enterprises' savings caused by global instability, lowering of incomes and negative development trends of the whole industry.

On average, the spendings of both foreign and internal tourists in the analyzed 48 countries were 4.3 trln USD back in 2019, and in 2020 they were already 2.15 trln USD. Considering the dynamics of tourism multiplier back in 2019, the indirect income from tourism was around 1.9 trln USD, and in 2020 it was already 0.79 trln (that is, the drop was $58 \%$, thus being more serious than the fall of direct tourism incomes during 2020 by at least $9 \%$ due to the tourism multiplier going down). Figure 1 demonstrates visually the analysis of two indicators - the level of tourism spending drop (both foreign and internal) and the level of GDP drop - for the selected 48 countries of the world. According to Figure 1, the direct incomes from tourism sectors in the analyzed countries have dropped by two-digit numbers, from 30 to $85 \%$ during 2020 , while GDP values of the same countries were falling in the range from less than $1 \%$ to $10 \%$.

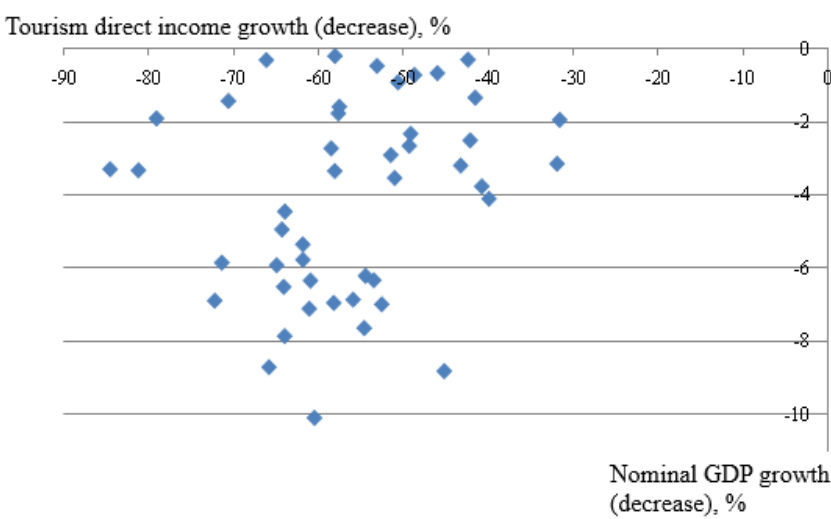

Figure 1. Reduction in direct incomes from tourism as compared to overall reduction in GDP in the selected countries, 2020 (compiled by the authors)

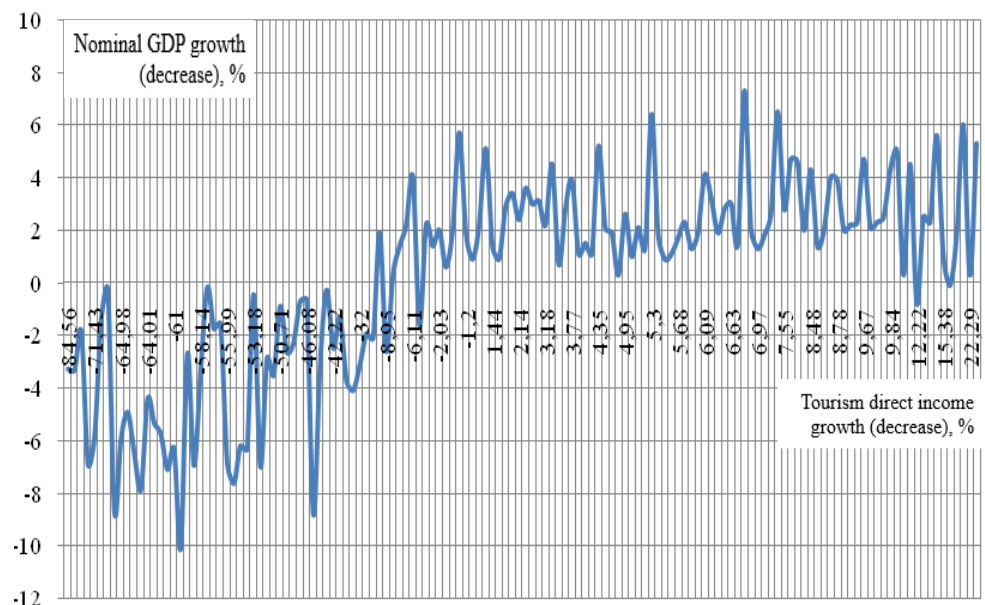

Figure 3. Dependence between direct incomes in tourism and the GDP dynamics in the selected countries, 2018 to 2020 (compiled by the authors)

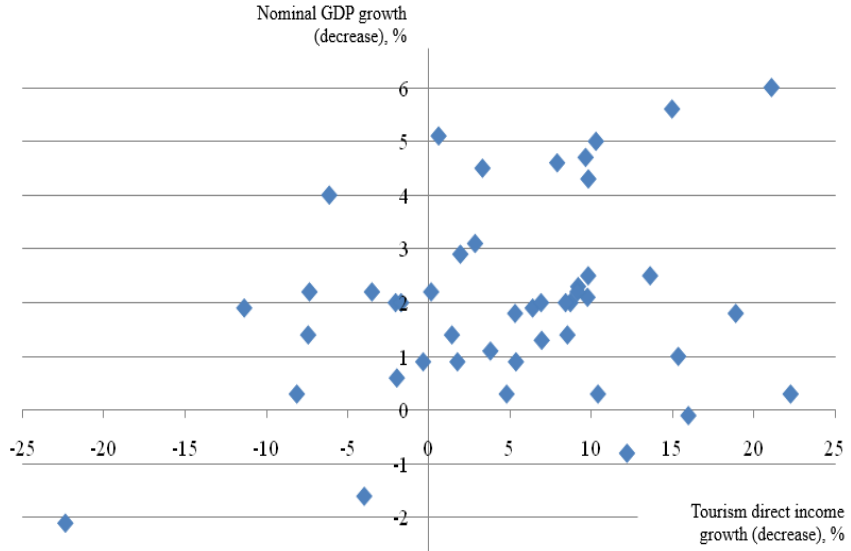

Figure 2. Volumes of direct incomes from tourism and GDP dynamics in the selected countries of the world, as of 2019 (compiled by the authors)

Table 5. Tourism multiplier in the selected countries, as of 2020 (calculated by the author)

\begin{tabular}{|c|c|c|c|c|}
\hline Groups & $\begin{array}{c}\text { Reduction of } \\
\text { indirect } \\
\text { incomes } \\
\text { from tourism } \\
\text { in 2020, in \% }\end{array}$ & $\begin{array}{c}\text { Number } \\
\text { of } \\
\text { countries } \\
\text { in the } \\
\text { group }\end{array}$ & $\begin{array}{c}\text { Average } \\
\text { reduction } \\
\text { of GDP } \\
\text { within the } \\
\text { group, in \% }\end{array}$ & $\begin{array}{c}\text { Tourism } \\
\text { multiplier, } \\
\text { group } \\
\text { average }\end{array}$ \\
\hline 1 & over 80 & 2 & 3.29 & 1.12 \\
\hline 2 & $70.1-80$ & 4 & 4.01 & 1.14 \\
\hline 3 & $60.1-70$ & 12 & 6.11 & 1.3 \\
\hline 4 & $50.1-60$ & 15 & 2.44 & 1.31 \\
\hline 5 & $40.1-50$ & 11 & 3.05 & 1.34 \\
\hline 6 & $30.1-40$ & 4 & 2.53 & 1.69 \\
\hline
\end{tabular}


To compare negative and positive dynamics of the tourism sectors development, let us give the same visual presentation for the 2019 data as well, since during that year the direct incomes from tourism were overall growing (Figure 2).

The graph in Figure 3 clearly demonstrates there is a certain regularity in the growth indicators of the nominal GDP of the selected countries and their direct incomes from tourism. In 48 analyzed countries and in the half with positive values, the growth of direct incomes from tourism (up to 23\% per year) is associated with the growth of nominal GDP (around $7 \%$ ). In some cases, the drop in direct income from tourism (even if it was as deep as $-9 \%$ per year) did not seem to cause a reduction in nominal GDP.In that part of the graph where reduction of incomes from tourism is most serious (10\% and more) we are observing a stable reduction of nominal GDP, however, it is also around $10 \%$.

Assessing the correlation between the indicators of direct incomes from tourism and the nominal GDP we have detected that if we extend the duration of the analyzed period (from one year to three years), the correlation indicators start growing. Thus, for the year 2020 alone the correlation indicator is 0.22 , for 2019 it is 0.29 , and if we take the period of 2019-2020, then the correlation indicator becomes 0.81. Finally, for the period from 2018 to 2020 it would be 0.833 .

At the final stage of our investigation we have assessed the values of tourism multiplier in the analyzed countries as of 2020, dividing our general sample into six groups, depending on the dynamics of direct tourism incomes reduction (Table 5). As it may be seen in Table 5, the value of tourism multiplier is decreasing from group to group, thus reaching its very minimum in the group with the maximum drop in the tourism sector indicators in 2020.

\section{CONCLUSION}

The global collapse of international and internal tourism in 2020 revealed itself through much smaller contribution of tourism in GDPs of all countries around the world (from 32\% to 85\% among the analyzed countries only). At this, reducing dynamics of the economic value of tourism in each country separately has been under the impact of multiple factors at the same time - not only macroeconomic indicators achieved back in 2019 or the shares of tourism sectors within the economic systems of various countries of the world, but also other, such as the efficiency of state stimulation measures under the pandemic conditions, the structure of internal and outbound tourist flows (for example, the shares of beach, ski, business, healthcare, and educational tourism, all of which have been suffering from the pandemic to very varying degrees, actually). Other factors also include the share of outbound tourism in a particular country and even the geographical sizes of the country and its potential to boost internal tourism under minimum time during the pandemic already (Our Hypothesis 1 has been rejected). The growth in the share of internal tourism within the total tourism incomes during 2020 is in reverse correlation with the dynamics of tourism incomes reduction during the same period (-0.755). This allows us to confirm Hypothesis 2 stating that in the absolute majority of countries the potential of internal tourism has turned out to be not sufficient for stabilization of the whole sector under the conditions when all international travels have been strictly limited.

Our analysis also shows that there is no significant correlation between the dynamics of the efficient tourism multiplier and the development indicators of the tourism sectors in the analyzed countries (the correlation indicators are within the range from - 0.023 to 0.23 back in 2018). Thus, our Hypothesis 3 is rejected. Evaluation of the correlation indicators from various time periods confirms there is a long-term trend (over one calendar year) in the direct correlation between the indicators of changes in direct incomes from tourism and the nominal GDP of the country. Thus, our next hypothesis can be confirmed only partially. Direct mutual dependence between the drop in direct incomes from tourism and the dynamics of nominal GDP is rather high, however, only under the condition the analysis is carried out for the period of over two years, while when analyzed for one year only, the indicators of GDP and tourism incomes do not seem to be correlated at all.

On the one hand, this confirms strong dependence of national GDP from the direct incomes in tourism (which is not surprising, actually), however, on the other hand, there is also a rather long-term lag in how tourism impacts on the overall state of a country's economic system. According to our estimations, this lag is at least one year (or more). Within the time period of less than one year, the dynamics of direct tourism incomes and changes in a country's GDP are divergent. In other words, a fall in direct incomes from tourism in a current year are not able to cause reduction in the nominal GDP in the same year, moreover, they are not even able to stop GDP growth (see, for example, the results for Pakistan, India, Azerbaijan, Brazil and Peru as of 2019, or China and Viet Nam as of 2020).

Most probably, consequences from reduced incomes in tourism would reveal themselves in the nominal GDP reduction in the next year (for example, in Pakistan under the tourism incomes reduction by $1.6 \%$ the economic growth of the country dropped from $5.7 \%$ back in 2018 to as little as $1.9 \%$ in 2019). Similar correlation can be observed in the data as of 2020, the year which was critical for the world tourism sector in particular and the international economy overall.

Some countries were experiencing reduction in tourism incomes in 2019 already. Then, in 2020, when tourism incomes fell even more, their GDP suffered much more greatly than GDPs in other countries. For example, in both Argentina and Pakistan tourism incomes during 2020 dropped by about 40-45\%, however, Argentina's GDP (in this country tourism incomes were gradually reducing since 2018) fell by 9\%, while in Pakistan the drop in GDP was less than $1.5 \%$. Similarly, in India and Switzerland the drop in tourism incomes was 55\%, however, their drops in GDPs were 6.9\% and $1.8 \%$ respectively. At this, in India direct incomes from tourism started falling back in 2019 already (by 6\% a year).

Therefore, we can conclude that dramatic falls in direct incomes from tourism in many countries of the world back in 2020 are yet to be revealed in the nominal GDPs of these countries. Most probably, we will observe these negative consequences in 2021 already, even though tourist flows in some countries have been partially restored by now.

Extrapolating the indicators of correlation (0.83) from the period of 2018-2020 (that is, on three years) onto the period of 2019-2021 we can calculate that for stopping further fall of economic indicators in the analyzed countries they would need to demonstrate the growth (!) of tourism incomes by at least $7.2 \%$ (average for 48 countries). At this, Peru, 
Argentina, Spain, Greece and Tunisia, for example, would need to demonstrate tourism income growth as high as 13 $15 \%$, while for Sweden, Denmark and New Zealand even 1\% growth in direct incomes from tourism during 2021 should be enough. Majority of larger economic systems, including the USA, Russia, UK and Germany, are in the range of 6.5$11 \%$. Our analysis of the efficient tourism multiplier values for the selected 48 countries of the world has confirmed its overall reduction (that is, according to our methodology of the tourism multiplier calculations, there is a decreasing stimulating contribution of direct incomes from tourism into GDP) while incomes from tourism overall were going down throughout the whole 2020. This confirms the initial hypothesis that the efficient tourism multiplier does not have a growing snowball effect since it can be working both ways - in the direction of positive dynamics of the national tourism development and in the reverse direction. Also, efficient tourism multiplier seems to be subject to the law of diminishing utility (when tourism demonstrates growth (Bajracharya, 2018) and then also to the law of accumulating uselessness (when tourism incomes drop). The accumulated uselessness of tourism industry is manifested through the destimulating and imbalancing effect on the economic system overall which may reach its peak even when tourism falls insignificantly, thus causing collapse in many other related sectors and subsectors along with capital outflow, raising unemployment, range of bankruptcies, disruptions in the international production \& distribution chains and so on. Since this is exactly the opposite of what causes the growth of tourism for an economic system as a whole, we have been forced to switch from the terminology "utility" to introducing the term of our own - "accumulating uselessness".

When tourism incomes reduce insignificantly (by 5-10\%), the uselessness would not be meaningful yet, since at that stage businesses, public authorities and general population usually start to acknowledge the value of tourism (which is temporary lost) and take efforts to restore it (through lower taxes, preferential crediting, more advertising and so on).

Of vital importance would be also changes in business perceptions and attitudes: it was just yesterday when local businessmen were taking crowds of travellers for granted, thus speculating on prices, introducing extra taxes on foreign tourists, not paying attention to the quality of services, wiping out capital from the country/region and optimizing own expenses (through semilegal and illegal financial scheming, illegal employment of labour migrants, crediting abroad, etc.). In other words, local businesses were feeling the diminishing economic utility from tourism which was accompanying its stable, even though not too dynamic growth. And now, under the conditions of reduced tourism inflows, the effect of diminishing utility has been substituted by its exact opposite — the effect of low uselessness.

At the same time, with a deeper fall in tourism indicators its uselessness seems to be rising. Let's take the Thai island of Phuket which experienced tourism numbers going down by $80-85 \%$ as an example to show the key stages in the growth of economic uselessness of tourism. When tourism fell by about $40 \%$, local businesses were still trying to survive, asking for government support and referring to the importance of their sector for the local economy, its future prospects and so on. Businesses were also making attempts to reduce the prices, minimize own expenses, firing some of the employees. All these attempts have only made the quality of the local services go down, thus pushing away the still remaining few tourists. All tourism-related assets also went down in their value/price, including buildings, land, securities of tourism corporations, etc. Many enterprises stopped paying under their credits, thus, local debts went up. When tourism fell to the level of $50 \%$, majority of small and mid-sized tourism enterprises simply left the market; local assets became depreciated; local level of life quality went drastically down; local government's spending on utilities, police and public transport was minimized to the lowest level possible. When tourism fell by 60, a wave of bankruptcies among large enterprises started to emerge. Thus, local assets became entirely depreciated, some of them were bought out by the businesses from other, less damaged sectors (private developers, transport and logistics companies, agrarian and industrial companies). Both government and banks stopped their financial support of failing tourism businesses, fearing that the wave of bankruptcies would go further, onto other sectors.

Finally, when tourism fell by $70 \%$, the local population started leaving tourism resort areas, and local tourism assets quickly became delapidated. Local authorities had zero budgets to support tourism or even municipal basic infrastructure, thus whole districts were cut off and left without electricity, water supply, and garbage disposal services. Local transport was reduced to the absolute minimum, same with local trade, while criminality rates were inevitably going up. At that point, tourism was obviously not considered any longer as a promising sector with a bright future. Instead, it was seen as a sector requiring radical reformatting, new development tools and a new mode of integration into the national economic system.

Thus, our initial assumption about the accumulating economic uselessness of tourism has been statistically proven on the 2020 data. This crisis year actually became the first year to provide data for testing tourism behavior under the unfavorable conditions for development. And this data, in its turn, has helped us prove that once tourism numbers fall by $40 \%$, its contribution to GDP becomes smaller than that of a traditional (not high-tech) agriculture and trade. According to the data presented in Table 5, tourism multiplier is less than 1.35, thus, it becomes comparable with the agriculture's multiplier in developing countries (around 1.4) and trade multiplier (1.32).

Accumulating uselessness achieved when tourism falls by $40 \%$ provides an opportunity to substitute tourism with more traditional sectors (namely, agriculture and trade). This substitution does not require huge investments, while world infrastructure of these sectors, even though volatile, demonstrates some improvement, unlike tourism in 2020.

\section{RECOMMENDATIONS}

The presented here results are mostly theoretical in their nature, however, they are oriented on developing radically new conceptual grounds for further development of the global tourist market and national tourism sectors. Our results, inter alia, allow outlining several recommendations on the measures of public regulation and strategic planning in tourism.

When determining the economic utility of tourism, it seems to be feasible to apply the methodology of the efficient multiplier calculations as it is initially based on the difference between direct incomes from tourism (spending by internal 
and foreign tourists) and the necessary exclusions from these incomes (foreign credits, franchise payments, taxes, etc.), thus forming the accumulation ratio. Unlike some other, alternative methodologies of the tourism multiplier calculations, the one suggested in this study may show the multiplier values being below 1 . This would mean that GDP of a country gets less assets from foreign tourists. In our view, this reveals the actual situation in the sector in a much more realistic way. Multiplier thus turns into what we name here miniplier which, in its turn, reduces the actual economic efficiency of tourism spending. In this case, experimental calculations of tourism multiplier would demonstrates its values as being around 3-4, and this, in our opinion, does not reflect the actual situation in the sector and economies overall.

In the situation when the tourism sector collapses (as nowadays), both public authorities and local businesses need to take into account the principle of accumulating uselessness from tourism. When this principle is observed in real-life economic situations, the damaging effect from tourism fall for the whole economy would be usually observed only during the first stage. With the course of time, when tourism assets start falling in their price, tourism labour resources are being shifted to other sectors and regions and crediting of tourism is stopped as such, the tourism sector becomes gradually substituted by other sectors and/or requires radical reformatting which would become the basis for its future restoration.

\section{REFERENCES}

Archer, B.H., \& Owen, C.B. (1971). Towards a tourist regional multiplier. Regional studies, 5, 289-294.

Ardahaey, F.T. (2011).Economic Impact of Tourism Industry. International Journal of Business and Management, 6(8), $206-215$. https://doi.org/10.5539/ijbm.v6n8p206

Armstrong, H., \& Taylor, J. (1985). Regional economics and policy. Oxford: Philip Allen.

Bajracharya, S. (2018). Law of Diminishing Marginal Utility: Assumptions and Exceptions. Businesstopia, 11.01. https://www. businesstopia.net/economics/micro/law-diminishing-marginal-utility

Brohman, J. (1996). New Directions in Tourism for Third World Development. Annals of Tourism Research, 23(1), 48-70. https://doi.org/10.1016/0160-7383(95)00043-7

Butler, J. (2012). Hotel Lawyer with the new "Guide” for international hotel transactions - doing business abroad or with foreigner. https://hotellaw.jmbm.com/foreign_deals_and_investors.html

Bycroft, P., Dyer, P., \& Nash, D. (2007). Serious Business Beyond Tourism: Attracting Retaining High Value Low Impact Industries to Regional Economies. Australian Journal of Regional Studies, 13(2), 205-220.

Clulow, V., \& Walters, G. (2013). Issues in Sustainable Tourism. The International Journal of Sustainability Policy and Practice, 8(3), 11-19. https://doi.org/ 10.18848/2325-1166/CGP/v08i03/55381

Coccossis, H., \& Nijkamp, P. (1995). Sustainable tourism development. Aldershot: Avebury.

Idahosa, L. (2019). Understanding Sustainability, Corporate Social Responsibility And Responsible Tourism In Literature Vs Practice. Geojournal of Tourism and Geosites, 26(3), 956-973. https://doi.org/10.30892/gtg.26322-410

Kim, H., \& Kim, B.G. (2015). Economic impacts of the hotel industry: an input-output analysis. Tourism Review, 70(2), $132-149$. https://doi.org/10.1108/TR-11-2014-0056

McDonald, J. (2009). Complexity science: an alternative world view for understanding sustainable tourism development. Journal of Sustainable Tourism, 17(4), 455-471. https://doi.org/10.1080/09669580802495709

Merrifield, J. (2006). A Neoclassical Anatomy of the Economic Base Multiplier. Journal of Regional Science, $27(2), 283$ - 294. https://doi.org/10.1111/j.1467-9787.1987.tb01160.x

Milne, S., \& Ateljevic, I. (2001). Tourism, Economic Development and the Global-Local Nexus: Theory Embracing Complexity. Tourism Geographies, 3(4), 369-393. https://doi.org/10.1080/146166800110070478

Milne, S.S. (1987). Differential multipliers. Annals of tourism research, 4, 499-515.

Milne, G., \& Bruijn, M. (1991). Tourism: emphasis on selective development. M.A. Thesis, Vrije Universiteit, Amsterdam.

Pilon, A. (2020). 12 Best Hotel Franchise Choices. Available online: https://smallbiztrends.com/2020/11/hotel-franchise.html

Pleeter, S. (1980). Economic Impact Analysis. Boston: Kluwer.

Rusu, S. (2011). Tourism multiplier effect. Journal of Economics and Business Research, XVII (1), 70-76. https://doi.org/TC360data. Statistic data. https://tcdata360.worldbank.org/topics

Verdonkschot, S. (1994). Sustainable tourism development. M.A. Thesis, Vrije Universiteit, Amsterdam

*** Statistic data. Travel and Tourism economic impact. https://wttc.org/Research/Economic-Impact

Article history: Received: 07.07.2021 Revised: 28.11.2021 Accepted: 06.12.2021 Available online: 31.12 .2021 